УДК 159.95

doi: $10.15330 / p s .10 .1 .21-29$

\title{
Микола Папуча
}

Ніжинський державний університет імені Миколи Гоголя

nikolay.papucha@gmail.com

\section{Марія Наконечна}

Ніжинський державний університет імені Миколи Гоголя maria.nakonechna2014@gmail.com

\section{КУЛЬТУРНО-ІСТОРИЧНА ТЕОРІЯ ТА МЕТОДОЛОГІЯ Л. С. ВИГОТСЬКОГО}

\begin{abstract}
У статті доводиться, щзо Л. С. Виготський створив нову, справжню методологію, застосування якої дало змогу отримати $i$, головне, проінтерпретувати абсолютно нові й дуже важливі наукові факти. Аналізуються методологічні основи та вимоги до психологічних досліджень. Історико-генетичний погляд як на будь-яке психологічне явище, так і на психологію особистості в цілому, є першою методологічною вимогою будь-якого психологічного дослідження. Друга вимога стосується самого аналізу (тлумачення) наукових фактів. Оскільки предмет дослідження (будь-яке психічне явище) існує в дійсності виключно в рамках цілісності, аналіз, щзоб бути науковим і об 'єктивним, мусить не втрачати цүю цілісність. По-третє, головна причина редукиї в сучасній психології полягає в тому, щзо реальні дослідження часто «зсуваються» з власне психологічного предмету. Наступним методологічним положенням є необхідність спеціального психологічного аналізу артефактів. Л. С. Виготський з'ясував і довів, щцо психічне детермінується психічним, адже потреби й мотиви - суто психічні явища. Інші речі - соціальне, духовне, біологічне, - безумовно, вступають у взаємодію з потребами, але самі ніколи не детермінують їх. Це є дійсно психологічна детермінація - вплив ціілого (психіки) на всі ї̈ складові частини. Істотною умовою тут виступає присвоєння культурного досвіду, опосередковане взаємодією з іншими людьми. Наголошується, що культурноісторична психологія особливим чином досліджує допомагальну взаємодію дорослого і дитини. У просоціальному плані - плані винесеного зовні, інтерпсихічного функціонування - вперше з'являсться вищза психічна функція, щзо переходить потім у внутрішній, згорнутий, інтрапсихічний план.

Ключові слова: Л. С. Виготський, культурно-історична теорія, методологія, вимоги, аналіз, просочіальна дія, допомога іншому.
\end{abstract}

Вступ. Дослідження в галузі психології особистості є чи не найчисленнішими в нашій науці. При цьому, однак, вони залишаються частковими (присвячені певному явищу чи процесу) і не об'єднаними внутрішньою логікою. Отже, маємо строкатість, яка, за визначенням, не може дати цілісної картини психічного життя людини.

Ми вважаємо, що такий стан речей зумовлений відсутністю єдиної методологічної бази. Персонолог, керуючись житейським досвідом та окремими філософськими побудовами, «створює власну теорію» й іноді переходить одразу до емпіричних досліджень. Розриви в ланці «філософія - теорія - методологія - методи - емпіричне дослідження» призводять до того, що в дійсност, психологія особистості проходить суто описовий етап, який явно затягнувся...

Необхідна методологія, яка б, з одного боку, змістовно узагальнила існуючі філософсько-теоретичні погляди i, з іншого, природно, дозволила створити метод, адекватний об’єкту - психічному життю людини.

Коли в 20-х роках минулого сторіччя Л. С. Виготський писав грунтовну працю «Історичний сенс психологічної кризи» [2], було дві психології, таких же немічних в методологічному плані, як і зараз. Але зараз психологій стало багато (чи не тому, що впала відповідальність і дуже багато дослідників вважають себе здатними, ба більше, вважають своїм обов'язком створити нову, власну психологію, психологію «імені себе»?).

Проте геніальний Л. С. Виготський за десять років (і яких років - тільки-но закінчилась революція і громадянська війна), в перервах між лікуванням загострень туберкульозу, створив нову, справжню методологію, застосування якої дало змогу отримати i, головне, проінтерпретувати абсолютно нові й дуже важливі наукові факти. Чому ця 
методологія не використовується - питання складне, і не тут його вирішувати... Ми просто спробуємо проаналізувати певні факти з точки зору методології культурно-історичної психології. Що це, власне, означає? Це означає виконання кількох фундаментальних вимог при проведенні психологічного дослідження - як теоретичного, так і емпіричного. Перш за все досліджується не явище, а процес. Отже, кожне явище буде адекватно зрозуміле, якщо ми будемо розглядати його в русі, як органічну частину цього руху. Тож нам треба не лише описати і витлумачити самий факт, а дослідити його походження (минуле) і можливості подальшого розвитку (майбутне). За Виготським, лише таке пізнання, яке охоплює явище в його русі, як момент, мить цього руху, лише таке пізнання буде адекватним. Що є рух? Л. С. Виготський доводить, що розвиток психіки людини є не природний процес, це є історія. Отже, дослідити явище означає дослідити його історію [4].

Отже, психологію необхідно з'єднати з історією. Але не будь-яку психологію і будь-яку історію (метафізично можна з'єднати взагалі будь-що з будь-чим). Історія людини і психологія людини - дві окремі лінії розвитку, які складно переплітаються, утворюючи багатогранну єдність. Саме це переплетення ми й будемо намагатися показати. Доречно тут навести думку М. Коула, який на підгрунті емпіричних фактів намагається показати, як саме з'єднуються ці «дві історії». М. Коул стверджує, що центральне місце в діалектиці розвитку людини належить культурі $[10$, с. 9]. Остання розуміється як сукупність артефактів - історичних перетворень людьми об'єктів матеріальної і, додамо, ідеальної дійсності. Оскільки культура є продуктом історії, то навіть у матеріальній культурі втілені людські ідеї, прагнення і переживання, відтак артефакти можна розглядати як водночас ідеальні (символічні) і матеріальні утворення [7, с. 492]. Розвиток психіки людини (вищих психічних функцій) являє собою, з цієї точки зору, активне оволодіння дитиною ідеально-психологічним змістом численних артефактів. Цей процес об'єднує в собі минуле (наявний досвід) і майбутнє. В цьому сенсі в західній психології вживається поняття «пролепса» («prolepsis»- випередження). В.В.Давидов наводить вдалий приклад М. Коула щодо ролі пролепса в культурному опосередкуванні розвитку [7, с. 492]. Подружжя, ще лише збираючись мати дитину, починає проектувати ії вірогідне майбутнє, тобто буквально уявляє майбутнє своєї дитини в теперішньому. Фактично, йдеться про те, що «ідеально-символічні спогади батьків про своє минуле і такі ж ідеально-символічні уявлення їх про майбутнє дитини організовують їі досвід в теперішньому» [7, с. 463]. Йдеться, власне, про згусток історичного буття дитини, що розвивається. Важливо додати слушну думку М. Коула про те, що для реалізації цього свого, практично, уготованого майбутнього дитині необхідно виявити власну соціальну інтелектуальну активність. Цим, власне, створюються нові артефакти даної людини. Це є іï початкові внески в історію людства 3 індивідуальною історією людини. Внески ці можуть бути представлені як матеріальні або ідеальні форми, але головне - вони мають бути. Це $є$ початок і продовження історії людини.

Зазначимо в дужках, В. В. Давидов в усній бесіді дуже коротко і ємко сформулював власну тезу. На питання, коли ж виникає особистість, він відповів: вона виникає 3 того часу, коли батьки починають іiі бажати, думати про неї, проектувати іiі життя.

Отже, історичний, точніше - історико-генетичний - погляд як на будь-яке психічне явище, так і на психологію особистості в цілому, є першою методологічною вимогою будь-якого психологічного дослідження. Тобто - це перша вимога до методу дослідження. Л. С. Виготський писав: «Немає розвитку, немає історії - немає сенсу і значення» [8, c. 256]. Друга вимога стосується самого аналізу (тлумачення) наукових фактів. Аналіз у психології є абсолютно необхідним, як, власне, і в будь-якій іншій науці. Але існує серйозна відмінність: оскільки предмет дослідження (будь-яке психічне явище) реально існує виключно в рамках цілісності, аналіз, щоб бути науковим і об' єктивним, мусить не втрачати цю цілісність. Це, по-перше. По-друге, аналіз у психології, як і в будь-якій науці, має не лише описувати, а й знаходити об'єктивно існуючі детермінанти, фактори, джерела, дії яких призводять до виникнення певних явищ і визначають їх подальшу долю. По-третє, аналіз 
не повинен виходити за межі психології: він може враховувати явища не психологічної природи, що мають відношення до предмету вивчення, але не може зосереджуватися на них, непомітно підміняючи предмет дослідження.

Почнемо 3 першого. Будь-яка наука, в тому числі й психологія, вимагає аналізу. Вивчати такі глобальні цілісності, як психіка, особистість, свідомість, несвідоме еtс не можна, якщо залишатися в межах науки. Але при штучному розтині цих цілісностей ми неминуче, здавалось би, втрачаємо найголовніше - живий об'єкт дослідження. Психологія завжди так робила й робить. I не важливо, з якого боку розтинати - 3 духовного, біологічного чи психологічного. Важлива втрата живого об'єкту. Л. С. Виготський майже століття тому показав і в конкретному дослідженні втілив зовсім інший тип аналізу. Явище попередньо, аналітично розпадається не на окремі елементи, 3 яких потім не можна «зліпити» знову цілісність, а на специфічні «одиниці» $[2 ; 3 ; 4 ; 5 ; 6]$. «Перша властивість одиниці полягає у тому, що аналіз виокремлює такі частини цілого, які не втратили особливостей, що властиві цілому» [6, с. 35].

Друга властивість «одиниці» аналізу полягає в тому, що вона містить у собі в найпростішому «знятому» вигляді всю суперечливу єдність складових частин, які й роблять це утворення - даною, а не якоюсь іншою цілісністю. Відомо, що Л. С. Виготський використав даний вид аналізу при вивченні глобальної цілісності «мисленнєве мовлення» і виокремив «одиницю» аналізу - значення, яке зосереджує в собі всі складники i всі властивості мисленнєвого мовлення. Саме це дало змогу отримати й узагальнити емпіричні дані, що визнані в усьому світі. Ми бачимо сенс у використанні аналізу за «одиницями» в сучасній психології за умови, якщо вона хоче бути самостійною наукою.

Щодо детермінації. Зараз дуже поширюється думка, що психіка людини взагалі не детермінована, оскільки факти нібито говорять про абсолютну непередбачуваність поведінки людини. Думка, взагалі-то, далеко не нова, але бентежить, що вона поширюється саме в наукових колах. 3 іншого боку, дуже поширений сучасний біхевіоризм постулює стару ідею біологічної і соціальної детермінації людини через безпосередній вплив $\mathrm{S} \rightarrow \mathrm{R}$.

Ще з одного боку, поширений і дійсно дуже змістовний сучасний психоаналіз, прикриваючись виразом «психічне з психічного (несвідомого)», насправді продовжує традицію грубого біологізаторства. Детермінанти психіки - несвідомі потяги й інстинкти, тобто - суто біологічні явища.

Все це дуже відомі і давно розкритиковані погляди, але вони мовчазно приймаються психологами, поряд з такими ж давно відкинутими догмами, як детермінація духовна.

Натомість маємо чи не найбільше досягнення Л. С. Виготського в цьому напрямі. Саме він з'ясував і довів, що психічне детермінується психічним, адже потреби й мотиви суто психічні явища. Інші речі - соціальне, духовне, біологічне, - безумовно, вступають у взаємодію $з$ потребами, але самі ніколи не детермінують їх. Це є дійсно психологічна детермінація - вплив цілого (психіки) на всі іiї складові частини. Істотною умовою тут виступає присвоєння культурного досвіду, опосередковане взаємодією з іншими людьми.

По-третє. Головна причина редукції в сучасній психології полягає в тому, що реальні дослідження часто «зсуваються» з власне психологічного предмету. Наприклад, вивчаючи вплив на розвиток певних психічних явищ факторів соціального оточення, дослідники непомітно (можливо, й для самих себе) часто більше уваги приділяють саме цим факторам і лише «мають на увазі» те суто психічне, що заявлене як дійсний предмет дослідження. Цей «зсув» стосується не лише соціального, а й біологічного (яскравий приклад - так звані конституціональні теоріi), духовного, житейського. Утримати в центрі уваги са́ме психічне є важливою задачею i, водночас, фактором успішного дослідження в межах психології.

Наступним методологічним положенням є необхідність спеціального психологічного аналізу артефактів. Л. С. Виготський, нагадаємо, прийшов до відкриття специфіки психіки людини (вищих психічних функцій, - в його термінології), почавши саме 3 аналізу деяких артефактів. Він назвав їх окам'янілостями. Матеріальні чи ідеальні продукти 
людської активності є своєрідним відбитком цілісної психіки людини. Але це - лише один ï бік. Інше, дуже важливе, було помічено саме Л. С. Виготським - ці артефакти створюються людиною як засоби опанування поведінкою і власним внутрішнім світом: вузлик на пам'ять (зачаток писемного мовлення, за Виготським) - для опанування пам'яттю, жереб - для опанування собою в ситуації вибору еtс. Ці засоби, їх засвоєння і присвоєння дитиною і породжують управління собою - довільність, опосередкованість, усвідомлення, вольову регуляцію. Універсальним артефактом-засобом $є$ мовлення. Отже, дослідження виникнення культурних засобів та їх використання людиною насправді відкриває нечувані можливості вивчення особливостей психології людини. На жаль, ця методологема i конкретні дослідження в іiї межах самого Виготського не мали продовження навіть серед його учнів і колег.

Л. С. Виготський розробив і застосував «конструктивно-генетичний метод» (назва Л. С. Виготського). Зазначимо, що в методології Виготського методу взагалі належить центральна роль. Він писав: «метод $є$ водночас передумовою і продуктом, знаряддям і результатом дослідження» [4, с. 41]. Це, на наш погляд, глибоке філософсько-психологічне визначення, що починає й замикає все коло дослідження. Адже виходить, що метод взагалі не даний як такий, а лише заданий попередніми уявленнями і гіпотезами дослідження. Метод - розвивається в процесі дослідження, і саме тому є одним з його результатів. Спеціально зазначимо, що Л. С. Виготський принципово наполягав на відмінності методу і конкретних методик (ця більш ніж виправдана точка зору, на жаль, повністю ігнорується в сучасній науці). Підкреслимо ще раз, що, обгрунтовуючи свій метод дослідження, Л. С. Виготський гостро критикував наукову психологію, всі методи якої побудовані на грунті схеми $\mathrm{S} \rightarrow \mathrm{R}$. Ця схема призводить до повної редукції психології людини, зводячи ії (людину) до ролі маріонетки, що лише відповідає на подразнення. Конструктивно-генетичний метод кардинально відрізняється від інших тим, що його сутність полягає в тому, щоб надати змогу досліджуваному самому створити стимул для себе (це, власне, і є психічна детермінація на ділі). Фактично досліджуваний конструює власну реальність, яка містить всі особливості вищих форм його психіки. Ми не будемо тут відтворювати аналіз Л. С.Виготського щодо застосування даного методу. Звернемо увагу лише на одне, дуже важливе: метод, який використовує дослідник, є прямим втіленням його (дослідника) уявлення про людську психіку. Отже, дослідники, що використовують найрізноманітніші модифікації стимул-реактивної поведінки, розуміють психіку людини як суто реактивну. Це є характеристика науки та іï суб'єктів, і цю характеристику скасувати неможливо.

Зрозуміло, що таке обернення ситуації дослідження з необхідністю вимагає принципового перегляду поведінки і позиції дослідника. Виготський чи не вперше звернув увагу на це, що виявилося одним із факторів, які визначають його методологему, як початок постнекласичної психології. Л. С. Виготський підкреслює правильність думки Вунта, який вважав, що словесна інструкція кардинально відрізняється від інших стимулів. Виготський іде далі i, фактично, говорить про міжсуб'єктне співробітництво дослідника i досліджуваних. Він втілює цю думку у власних експериментальних роботах, але не встигає iї узагальнити й експлікувати в тексті. На жаль, ця принципова позиція якось не прижилася у психології. Щасливим винятком можна вважати дослідження в межах розвивального навчання (В. В. Давидов, Д. Б. Ельконін, В. В. Рєпкін та ін.) та натхненні роботи Ш. О. Амонашвілі.

Ми завершили викладання методологічної позиції, що трошки затягнулося. Це відома річ, і ми даємо собі звіт в цьому. Але, по-перше, ми повною мірою розділяємо і використовуємо цю методологію, по-друге, для досліджуваної тут проблеми це - єдино продуктивна методологічна база. $Є$ ще й третє - методологема Л. С. Виготського ніби реалізувалася в радянській психології, але в такому перекрученому вигляді, що іiі там важко впізнати. При цьому вона далеко не втратила своїх можливостей i, на нашу думку, має стати підгрунтям наукових досліджень в сучасній психології. 
Аналіз останніх досліджень. Свідомість пов'язана з допомогою іншому, оскільки справжня, дійсна допомога діалогічна і відкриває нові аспекти семіосфери свідомості. Справжня допомога вимагає усвідомленості і є медіатором відкритості свідомості і духовного становлення людини. Невротична допомога і псевдодопомога особливої усвідомленості не потребують і не сприяють виходу в нові шари свідомості, не ініціюють духовний і особистісний розвиток.

Свідомість діалогічна, поліфонічна, має структуру («смислова будова свідомості» [2]) і розвивається (саморозвивається). За Г. Г. Шпетом, свідомість не іманентна суб'єктові, вона не має «власника» (Див: [9]). К. О. Абульханова [1] же, дотримуючись діяльнісного підходу, розробленого С. Л. Рубінштейном, навпаки, вважає свідомість іманентною особистості. Ці дві позиції, ми вважаємо, є взаємодоповнювальними, оскільки є частка психологічної правди і в тій, і в іншій. Потрібна особлива методологічна робота, щоб окреслити точки зіткнення цих двох позицій і глибше зрозуміти сутність свідомості.

В основних положеннях доповіді Л. С. Виготського «Проблема свідомості» вказується: «Значення відноситься не до мислення, а до всієї свідомості» [2, с. 167]. Ця віднесеність значення до всієї свідомості проливає світло на проблему означення сенсів і осмислення значень. Якщо і значення, і сенси відносяться до всієї свідомості, то в складному русі останньої можливі взаємопереходи значень і сенсів. Крім того, слід відмітити, що значення допомагальної дії пов'язує цю дію зі свідомістю людини.

Свідомість людини розвивається. Л. С. Виготський довів, що значення розвиваються, а якщо розвиваються ці одиниці мислення і мови, то розвивається і те ціле, у що вони включені - людська свідомість. Втім, теза про те, що свідомість (само)розвивається, може бути обгрунтована з різних точок зору. Просоціальна активність людини також розвивається. Поки що важко виділити одиницю такої активності. Імовірно, такою одиницею $є$ акт допомоги іншому. Різноманітні форми і способи здійснення просоціальної активності. Феноменальна за своєю різноманітністю онтологія і гносеологія людської свідомості. Звичайно ж, це приводить до думки про те, що свідомість і просоціальна активність тісно взаємозв'язані.

Чи може просоціальна активність бути несвідомою? Несвідомість як негативна характеристика відсутності свідомості в одній із ланок просоціальної діяльності, поза сумнівом, може бути властива людині, що допомагає іншому. Прикладом може бути імпульсивне або компульсивне надання допомоги. Імпульсивна просоціальна активність - це система дій, мотивом яких є раптово виникла і найчастіше неусвідомлювана спонука допомогти іншому. Імпульсивна допомога частково неусвідомлювана: якщо мотивація цих дій може бути несвідомою, то самі дії усвідомлюються суб'єктом. Компульсивне надання допомоги - це нав'язливе прагнення облагодіяти інших. Компульсивна і невротична допомога дуже тісно пов'язані: по суті, перша є різновидом другої.

Мета статті - презентувати результати методологічного аналізу особливостей дослідження психічного життя людини та просоціальної активності особистості.

Виклад основного матеріалу дослідження. Просоціальна дія - це одиниця просоціальної активності особистості. Якщо ми зрозуміємо генезу просоціальної дії, наприклад, дії допомоги іншому, ми розкриємо основні закономірності генези просоціальної активності особистості. Один із продуктивних шляхів у цьому напрямку пропонує нам культурно-історична психологія Л. С. Виготського.

Культурно-історична психологія особливим чином досліджує допомагальну взаємодію дорослого і дитини. У просоціальному плані - плані винесеного зовні, інтерпсихічного функціонування - вперше з'являється вища психічна функція, що переходить потім у внутрішній, згорнутий, інтрапсихічний план.

Л. С. Виготський писав: «Оволодіти правдою про особистість і самою особистістю не можна, поки людство не оволоділо правдою про суспільство і самим суспільством» [2, c. 436]. Аналогічно можна стверджувати, що поки ми не оволоділи правдою про суспільство, доти ми не зможемо повністю зрозуміти феномен просоціальності. Тріада осо- 
бистість - суспільство - просоціальна активність була і залишається terra incognita, скільки би не створювалося теорій особистості, концепцій суспільного чи морального розвитку. Зрозуміти сутність проблеми просоціальної активності - означає доторкнутися до сутності суспільних і міжособистісних процесів у цілому.

Особистісне і просоціальне в нас - це та тонка грань, де зовнішнє стає внутрішнім, спільне - приватним, а виражене інтрапсихічно - вираженим зовні. Тут народжується «моральний закон у мені» (I. Кант), тут він розвивається і стає іманентним і мені, і іншому, і нашій спільній діяльності, а точніше - спільно розподіленій діяльності. I тоді діяльність виявляється причетна до особистості, особистість - до суспільства, суспільство - до просоціальності і моралі. Просоціальне ставлення особистості до Іншого конституює унікальний і неповторний світ, що $є$ водночас і світом зовнішнім, інтеріндивідним, i внутрішнім світом людини.

Особистість $є$ альфою і омегою просоціальної дії. Істинна, справжня просоціальна дія є наскрізь особистісною.

Допомога іншому може розглядатися 3 погляду культурно-історичної психології Л. С. Виготського як акт, спрямований на розширення зони актуального і найближчого розвитку того, кому допомагають. Побічним ефектом допомагальної взаємодії $є$ іiі розвивальний характер щодо суб'єкта, який допомагає. Допомагаючи іншому, розвиваєшся сам.

Сенс допомоги іншому в опануванні власною поведінкою полягає у привнесенні знаку, означенні певних дій і структур. Процес інтеріоризації як подвійний процес перенесення всередину зовнішніх опор і переходу від звернення до іншого до дії на себе $\epsilon$ сутнісним для розуміння просоціальної активності. У просоціальній активності, зокрема в таких iї формах, як допомога, емпатія, доброчинність інтерпсихічні функції стають інтрапсихічними. Просоціальна активність, перефразовуючи Л. С. Виготського, з'являється на сцені двічі: спочатку як функція колективна, потім як внутрішнє ставлення до Іншого.

Допомагальна взаємодія припускає стрибок у розвитку. Ось у суб'єкта отримання допомоги формується запит; ось шукаються способи вирішити поставлену проблему. І ось інсайт, осяяння, здогадка. У допомагальній взаємодії інсайт діалогічний: це внутрішнє продовження зовнішнього діалогу. I навіть коли йдеться про самодопомогу, інсайт діалогічний: це нелінійна, стрибкоподібна, вибухова розмова з собою. Після такої розмови або діалогу людина стає відкритою для різних варіантів розвитку і подальшої активності; це «точка біфуркації», що відкриває множинність можливостей життя.

Активність, спрямована на благо іншого, стає засобом подолання суб'єктом самого себе і способом виходу людини в трансцендентну або ж суб'єктну позицію рефлексії. Реальна допомога, що надається в житті, може не бути так само схожою зовні на описані нами схеми, як не схоже (на думку Л. С. Виготського і Б. Спінози), сузір'я Пса на собаку, що гавкає на тварину. Проте глибокий психологічний аналіз феномена допомоги свідчить про те, що вимір суб'єктності завжди в ньому присутній.

Посередництво (у його розумінні Б. Д. Ельконіним) у ранньому дитинстві відповідає основним сутнісним характеристикам допомоги, де дорослий виступає суб'єктом, який допомагає. Таким чином педагогічна, навчальна дія є просоціальною за своїм характером.

Допомога як дія є мультисуб’єктною. Допомога іншому - це мінімум дві дії (дія суб'єкта, що надає допомогу, та дія суб'єкта, який отримує допомогу), а кожна 3 цих дій, за Б. Д. Ельконіним, є двосуб'єктною. Дія допомоги іншому задається континуумом орієнтування «для себе» та «для іншого» в онтології продуктивної дії людини.

«Суб’єктність - це певний режим життя, а не характеристика індивіда, який спостерігається» [11, с. 140], - пише далі Б. Д. Ельконін. Допомога іншому входить у режим життя просоціального суб'єкта, і в допомозі цей суб'єкт якнайповніше реалізує свою суб' єктність, переживаючи ії як зусилля та будучи посередником між способом виконання дії та іншим суб'єктом. Це посередництво нагадує відому притчу про те, що краще 
навчити голодного ловити рибу. Суб'єктність в оволодінні власною життєвою ситуацією одна із суттєвих ознак справжньої допомоги особистості.

Допомога іншому - це посередництво, яке ініціює та реалізує взаємоперехід реальної та ідеальної форм дії. Причетність (за Б. Д. Ельконіним) у допомозі переживається як відчуття себе частиною більшого цілого, а здійснення - як зусилля зі зміни об'єкта дії, яке водночас суб'єктивно відчувається як таке, що протистоїть суб'єкту, стимулюючи людину проявляти таку фундаментальну якість свого буття, як суб'єктність.

Допомога іншому предметна. Її предметом $є$ простір можливостей допомагання, тобто реалізації себе як допомагального суб'єкта в системі суб'єкт-об'єкт-суб'єктних відносин.

У свідомості проявляється просоціальна активність особистості, свідомістю вона породжується і їі ж розвиває. Просоціальна активність особистості здійснюється на всіх трьох структурних рівнях свідомості, виділених В. П. Зінченком: буттєвому, рефлексивному і духовному, але провідну роль, на нашу думку, відіграє духовний рівень, рівень Я - Ти.

Л. С. Виготський писав: «Свідомість відображає себе в слові, як сонце в малій краплі води. Слово відноситься до свідомості, як малий світ до великого, як жива клітина до організму, як атом до космосу. Воно і $є$ малий світ свідомості. Осмислене слово $є$ мікрокосм людської свідомості» [3, с. 361]. На наш погляд, осмислена допомога іншому $є$ мікрокосмом людського становлення, особистісного розвитку, розвивальної просоціальної активності. Свідомість відображається в допомагальній діяльності, відсіваючи зерна від полови: істинність, справжність допомоги від ії псевдо- і невротичних форм. У справжній допомозі так само важлива свідомість, як світ осмислених значень у макрокосмосі свідомості. Осмисленість $\epsilon$ найважливішою характеристикою справжньої допомоги.

Слово при наданні допомоги є медіатором, знаком, знаряддям, засобом, виразом i втіленням людської суб'єктивності й особистісності. Просоціальна активність вся пронизана словами, вимовленими чи ні. Словесне оформлення допомоги визначає іiі істинну або псевдо-форми. При дотриманні виділених К. Роджерсом умов емпатії, конгруентності і безоцінного безумовного прийняття словесний діалог суб'єктів надання й отримання допомоги справляє розвивальний вплив на їх особистість, свідомість і креативність.

Усвідомленість здійснення просоціальної активності є необхідною передумовою істинності, справжності допомоги, що надається. Усвідомленість у цьому випадку виявляється тісно пов'язаною з етичними вимірами людського життя.

У разі деструктивних форм просоціальної активності - псевдодопомоги і невротичної допомоги - здійснення просоціальної активності буде тісно пов'язаним з можливим наміром, маніпулятивними мотиваціями. Останні можуть бути усвідомлені або несвідомі, але у будь-якому разі вони не належать до духовних рівнів людської свідомості. Онтологія свідомості, ii біодинамічна і чуттєва тканина виявляються розузгодженими, роз'єднаними з духовністю людини, iї «Я» $\mathrm{i}$ «Ти».

Висновки. Допомога іншому опосередковує процеси розвитку свідомості й особистості. При цьому допомога іншому - це складна діалектична єдність безпосереднього й опосередкованого, свідомого і неусвідомленого, особистісного і діяльнісного. Культурноісторична концепція Л. С. Виготського дає нам ключ до розгадки питань, що вічно турбують душу людини, які наповнюються тепер конкретним науково-психологічним змістом.

Перспективи подальших досліджень пов'язані з проведенням емпіричних досліджень, які грунтуються на теоретичних поглядах Л. С. Виготського та пов'язані 3 проблемами психічного життя людини, зокрема у вимірі просоціальності. $2,80-95$

1. Абульханова, К. А. (2006). Способность сознания личности как субъекта жизни. Мир психологии,

2. Выготский, Л. С. (1982). Собрание сочинений: В 6-ти m. Т. 1. Вопросы теории и истории психологии. М.: Педагогика.

3. Выготский, Л. С. (1982). Собрание сочинений: В 6-ти m. Т. 2. Проблемы общей психологии. М.: Педагогика. 
4. Выготский, Л. С. (1983). История развития высших психических функций. Собр. соч.: В 6-mи m. Т. 3. М.: Педагогика.

5. Выготский, Л. С. (1984). Собр. соч. в 6-ти томах. Т. 4. М.: Педагогика.

6. Выготский, Л. С. (2001). Лекциии по педологии. Ижевск.

7. Давыдов, В. В. (1996). Теория развивающегго обучения. М.: Интор. Канон.

8. Записные книжки Л. С. Выготского. Избранное (2017). Е. Завершнева и Р. Ван дер Веер (Ред.). М.:

9. Зинченко, В. П. (2010). Сознание и творческий акт. М.: Языки славянских культур.

10. Коул, М. (1995). Культурные механизмы развития. Вопросы психологии, 3, 5-20.

11. Эльконин, Б. Д. (2001). Психология развития. М.: Издательский центр «Академия».

\section{REFERENCES}

1. Abul'hanova, K. A. (2006). Sposobnost' soznanija lichnosti kak sub'ekta zhizni [The ability of consciousness of personality as vital subject]. Mir psihologii [World of psychology], 2, 80-95. (rus.).

2. Vygotskij, L. S. (1982). Sobranie sochinenij: V 6-ti $t$. [Selected works. In 6 vol.]. T. 1. Voprosy teorii i istorii psihologii [Vol. 1. Questions of theory and history of psychology]. M.: Pedagogika. (rus.).

3. Vygotskij, L. S. (1982). Sobranie sochinenij: V 6-ti $t$. [Selected works. In 6 vol.]. T. 2. Problemy obshhej psihologii. [Vol. 2. The problems of general psychology]. M.: Pedagogika. (rus.).

4. Vygotskij, L. S. (1983). Istorija razvitija vysshih psihicheskih funkcij [The history of development of higher psychological functions]. Sobr. soch.: V 6-ti t. [Selected works. In 6 vol.]. T. 3. [Vol. 3]. M.: Pedagogika. (rus.).

5. Vygotskij, L. S. (1984). Sobr. soch. v 6-ti tomah [Selected works. In 6 vol.]. T. 4. [Vol. 4]. M.: Pedagogika. (rus.).

6. Vygotskij, L. S. (2001). Lekcii po pedologii. [Lectures on pedology]. Izhevsk. (rus.). Intor. (rus.).

7. Davydov, V. V. (1996). Teorija razvivajushhego obuchenija [The theory of moulding education]. M.:

8. Zapisnye knizhki L. S. Vygotskogo. Izbrannoe [L. S. Vygotsky's notebooks. Selected works] (2017). E. Zavershneva, R. Van der Veera (Ed.). M.: Kanon. (rus.).

9. Zinchenko, V. P. (2010). Soznanie i tvorcheskij akt. [The consciousness and the creative act]. M.: Jazyki slavjanskih kul'tur. (rus.).

10. Koul, M. (1995). Kul'turnye mehanizmy razvitija. [The cultural mechanisms of development]. Voprosy psihologii [Questions of psychology], 3, 5-20. (rus.).

11. Jel'konin, B. D. (2001). Psihologija razvitija [The psychology of development]. M.: Izdatel'skij centr «Akademija», 2001. (rus.).

\section{Mykola Papucha, Maria Nakonechna CULTURAL-HISTORICAL THEORY AND METHODOLOGY OF L. S. VYGOTSKY}

The article substantiates that L.S.Vygotsky created new real methodology, whose application gave an opportunity to get and most importantly, to interpret absolutely new and very important scientific facts. Methodological foundations and requirements psychological researches are further analysed. Historical-genetical perspective both on any psychological phenomenon and psychology of personality as a whole is the first methodological requirement of any psychological research. Second requirement concerns the analysis (interpretation) of scientific facts. As a subject of research (any psychical phenomenon) exists in reality exceptionally within the framework of integrity, thus analysis in order to be scientific and objective must not lose this integrity. Thirdly, main reason of reduction in modern psychology is that real researches often "shift" from actual psychological object. Next methodological statement is a necessity of special psychological analysis of artefacts. L.S.Vygotsky proved and explored that psychical is determined by psychical, because needs and motives are purely psychological phenomena. Other domains, such as social, spiritual, biological, undoubtedly interact with needs, but never determine them. Influence of the whole (psyche) on all its component parts is really psychological determination. Appropriation of cultural experience, mediated by co-operation with other people, stands here as a substantial condition. It is noted that cultural-historical psychology investigates helping cooperation between an adult and a child in a particular way. A higher mental function emerges for the first time within realm of interpsychological functioning, further shifing into internal, convolute, intrapsychological realm.

Keywords: L. S.Vygotsky, cultural-historical theory, methodology, requirements, analysis, prosocial action, helping other. 